\title{
A POLÍCIA DA DISTOPIA FUTURA: DREDD E A UNIFORMIZAÇÃO
}

\section{THE POLICE OF FUTURE DISTOPIA: DREDD AND THE UNIFORMIZATION}

Ramiro Giroldo'

RESUMO: O ensaio se propôe a fazer uma leitura da personagem Juiz Dredd, conforme representada na revista em quadrinhos britânica 2000 A.D. Criada por John Wagner e Carlos Ezquerra, a personagem será discutida à luz da tradiçăo literária distópica, a fim de colocar em maior evidência suas particularidades. Referências pontuais às duas adaptaçóes cinematográficas das histórias da personagem auxiliarăo na abordagem da relaçáo travada entre obras de teor subversivo e a indústria cultural. O conceito de indústria cultural cunhado por Theodor W. Adorno e Max Horkheimer será abordado, portanto. Acerca das especificidades da ficçâo científica, proposiçōes formuladas por Darko Suvin serăo de auxílio.

Palavras-chave: Juiz Dredd; ficçâo científica; utopia; distopia; violência.

ABSTRACT: The paper discusses the character Judge Dredd as depicted in the British comic book 2000 AD. Created by John Wagner and Carlos Ezquerra. The character will be discussed in the light of the dystopian literary tradition to put more emphasis on its particularities. Brief coments to the two cinematic adaptations of the characters' stories will aid to understand how the cultural industry deals with subversive works. The concept of cultural industry coined by Theodor W. Adorno and Max Horkheimer will be approached, therefore. About the specificities of science fiction, propositions formulated by Darko Suvin will be of assistance.

Keywords: Judge Dredd; science fiction; utopia; dystopia; violence.

Se os utopianos devem obedecer a uma estrita ordenaçăo de todos os aspectos de suas vidas, a fim de manter a ilha em que vivem estática e hostil às possibilidades de revoluçấo, o mesmo se verifica na odiosa distopia. Autoritário, o Estado distópico demanda o que Aldous Huxley chama de "excesso de ordem" (2000), uma hipertrofia

Doutor em Literatura Brasileira pela Universidade de Sáo Paulo. Professor Adjunto A, da Universidade Federal de Mato Grosso do Sul. Pesquisador de Literatura Brasileira Contemporânea, Ficçăo Científica, Utopia e Autoritarismo. 
estrita o bastante para garantir a estabilidade e restringir radicalmente o movimento. O resultado é nocivo ao elemento humano, aos cidadâos sob o jugo autoritário: "muita organizaçăo transforma homens e mulheres em autômatos, sufoca o espírito criativo e abole a mera possibilidade de liberdade". ${ }^{2}$

O objetivo é restringir as opçôes de escolha e, assim, inibir o olhar crítico acerca de um estado de coisas negativo. Dessa forma, o potencial de resistir é frustrado em seu nascedouro, simultaneamente a uma inadvertida afirmaçăo da necessidade de formular uma resistência. Ainda que com dificuldade, o típico protagonista distópico acaba por elaborar cognitivamente seu desagrado para com as forças que lhe aprisionam e condicionam a vontade.

Dada a importância dos mecanismos de controle para a manutençăo da distopia, as narrativas que podem ser enquadradas em tal paradigma genérico recorrentemente têm atribuído destaque às forças policiais, ao braço armado do Estado distópico. ${ }^{3}$ Os exemplos sâo bastante numerosos e variados; citemos alguns: em 1984, de George Orwell, uma das organizaçôes coercitivas é a Liga Anti-Sexo, que reforça a orientaçâo moralista imposta à populaçăo; em Fahrenheit 451, de Ray Bradbury, os bombeiros (firemen, no original) devem fiscalizar se há subversivos cultivando ilegalmente o hábito da leitura literária, e queimar todos os livros que encontrarem; em Nâo Verás País Nenhum (1985), de Ignácio de Loyola Brandăo, o nome dos policiais, "civiltares", é indício de um governo futuro em que procedimentos oriundos da ditadura militar brasileira se deixaram penetrar na instância civil; em Amorquia (1991), de André Carneiro, há uma inversăo do romance de Orwell na chamada Polícia do Sexo, que tem a funçâo de verificar se cada cidadăo está cultivando a promiscuidade de maneira irrestrita, como manda a lei do mundo futuro configurado no romance.

Guy Montag, protagonista de Fahrenheit 451, é particularmente significativo para a discussáo a ser aqui empreendida. Trata-se, afinal, de um exemplo modelar da personagem distópica que, embora inicialmente vinculada a uma força policial, acaba por perceber que há algo de negativo nos seus arredores. No princípio do romance, sente-se satisfeito com a funçăo que lhe é atribuída; năo por acaso, a primeira sentença da obra é "Queimar era um Prazer" (BRADBURY, [s.d.], p. 11). Progressivamente, porém, ele começa a questionar as imposiçóes estatais e a cultivar a leitura de textos literários, fazendo a transiçâo de autômato a homem provido de vontades, dono de uma individualidade avessa à obrigatória uniformizaçăo.

A personagem aqui em pauta, Juiz Dredd, insere-se de uma forma ou outra na tradiçăo de personagens distópicas cujas açōes pōem às claras as deficiências e contradiçôes do regime autoritário a moldar-lhes o comportamento. Dessa forma, cabe permitir que o contato com a tradiçăo distópica da literatura e com o referencial teórico-crítico dedicado a investigá-la ilumine a personagem.

Juiz Dredd tem suas histórias publicadas periodicamente desde o primeiro número da revista em quadrinhos britânica 2000 a. D., de fevereiro de 1977. Criado pelo

Traduçấo livre de "Too much organization transforms men and women into automata, suffocates the creative spirit and abolishes the very possibility of freedom" (HUXLEY, 2000, p. 22).

3 Notável exceçâo é Admirável mundo novo, de Huxley: no romance, o prazer ocupa o lugar da coerçâo como método de controle. Configura-se, assim, o paradigma que nomeia nossa obra Ditadura do prazer. 
roteirista John Wagner e pelo desenhista Carlos Ezquerra, a personagem se fez presente em outras mídias que năo a original, constituindo na indústria cultural uma imagem prontamente identificável: figurou, por exemplo, em videogames e em dois filmes de longa-metragem. O primeiro, Judge Dredd, é de 1995 e tem a direçăo de Danny Cannon; o segundo, Dredd, é de 2012 e foi dirigido por Pete Travis. Todas as histórias em quadrinhos aqui mencionadas foram publicadas no Brasil na revista Juiz Dredd Megazine, que teve vinte e quatro números lançados com distribuiçăo nacional entre 2013 e 2015, pela Editora Mythos. Também faz parte do recorte a ediçăo Especial de Natal de 2013.

Em Seis Passeios pelos Bosques da Ficçâo, Umberto Eco cunha proposiçôes de valia para a discussâo de personagens que se proliferam em outras narrativas além da primeiramente dada a conhecer, a matriz. Eco se vê às voltas com a "verdade" construída por cada texto ficcional:

À parte as muitas e importantes razóes estéticas, acho que lemos romances porque nos dăo a confortável sensaçăo de viver em mundos nos quais a noçăo de verdade é indiscutível, enquanto o mundo real parece um lugar mais traiçoeiro. [...].É possível inferir dos textos coisas que eles náo dizem explicitamente - e a colaboraçáo do leitor se baseia nesse princípio -, mas náo se pode fazê-los dizer o contrário do que disseram (ECO, 1994, pp. 97-98).

No breve ensaio "A literatura contra o efêmero", Eco retoma a formulaçăo por meio de uma visada complementarmente didática:

Foram emigrando de texto em texto (e, por meio de várias adaptaçōes, de livro para filme ou balé, ou da tradiçâo oral para o livro) tanto personagens dos mitos da narrativa "leiga”: Ulisses, Jasão, o rei Artur ou Percival, Alice, Pinóquio, D’Artagnan. Mas, quando falamos de personagens desse tipo, referimo-nos a uma determinada partitura? Vejamos o caso de Chapeuzinho Vermelho. As duas versóes mais célebres, a de Perrault e a dos irmáos Grimm, têm profundas diferenças. Na primeira, a menina é devorada pelo lobo, e a história termina aí, inspirando, portanto, severas reflexôes moralistas sobre os riscos da imprudência. Na segunda, aparece o caçador, que mata o lobo e devolve a vida à garota e à avó. Final feliz.

Pois bem, imaginemos uma măe que conte a história para seus filhos e a encerre com o lobo devorando Chapeuzinho. As crianças protestariam e pediriam a "verdadeira" história, aquela em que Chapeuzinho ressuscita, e de nada valeria a máe declarar ser uma filóloga estritamente ciosa das fontes literárias. As crianças conhecem uma história "verdadeira" em que Chapeuzinho de fato ressuscita, e essa história é mais afim à versăo dos Grimm que à de Perrault (ECO, 2001, p. 1).

O exemplo escolhido por Eco aparentemente escapa ao tipo de emigraçăo realizada por Dredd, porque neste a indústria cultural opera radicalmente no estímulo à produçăo sequencial de novas narrativas capazes de manter o sucesso de uma "franquia"4. Ainda assim, as formulaçóes de Eco săo de auxílio, pois possibilitam observar de que maneira um paradigma ficcional posto em cena nas narrativas matrizes das histórias

$4 \quad$ O uso do termo, aqui, pretende explicitar o manejo dos personagens como bens de consumo destinados a gerar lucro. 
em quadrinhos pode se modificar em adaptaçóes. Em outras palavras, possibilitam verificar se determinada "verdade" de uma história foi alterada ou mantida em outras histórias, e com quais resultados. Levando em conta que a adaptaçâo deve ser tomada como uma obra dotada de relativa autonomia, eventuais alteraçôes apenas levam a um julgamento de valor negativo se algo das narrativas matrizes se perder e nenhuma perspectiva capaz de promover novas leituras for acrescentada.

A concepçâo visual de Dredd sofreu duas alteraçôes perceptíveis no decorrer do longo histórico de publicaçăo ainda em curso: sua figura, originalmente longilínea, ficou embrutecida e musculosa; os contornos do capacete, antes compostos por linhas curvas, săo agora menos dinâmicos e mais bojudos. As características elementares, contudo, se mantiveram, e a aparência da personagem se faz ainda bastante reconhecível. Tal circunstância náo é exclusiva de Dredd: a alteraçăo sutil na concepçăo visual é uma marca recorrente em personagens de quadrinhos que figuram em publicaçôes por décadas a fio, diante da necessidade de adequaçăo à estética predominante em cada momento. Nas duas figuras seguintes, o Dredd dos anos de 1970 e o dos anos 2010:

Figura 1: Detalhe da página 62 da Juiz Dredd Megazine, n. 2

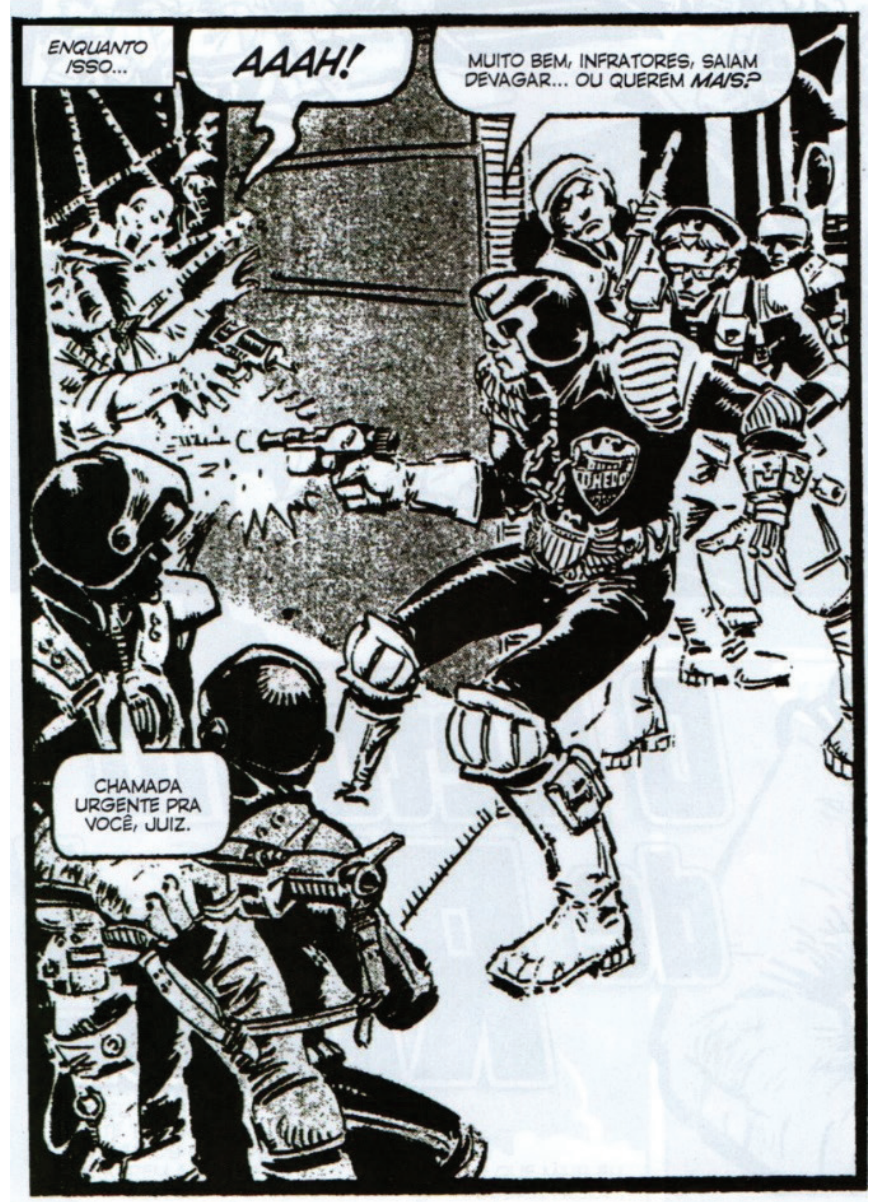

Fonte: MILLS, Pat; MCMAHON, Mike, 2013 
Figura 2: Detalhe da página 19 da Juiz Dredd Megazine n. 4

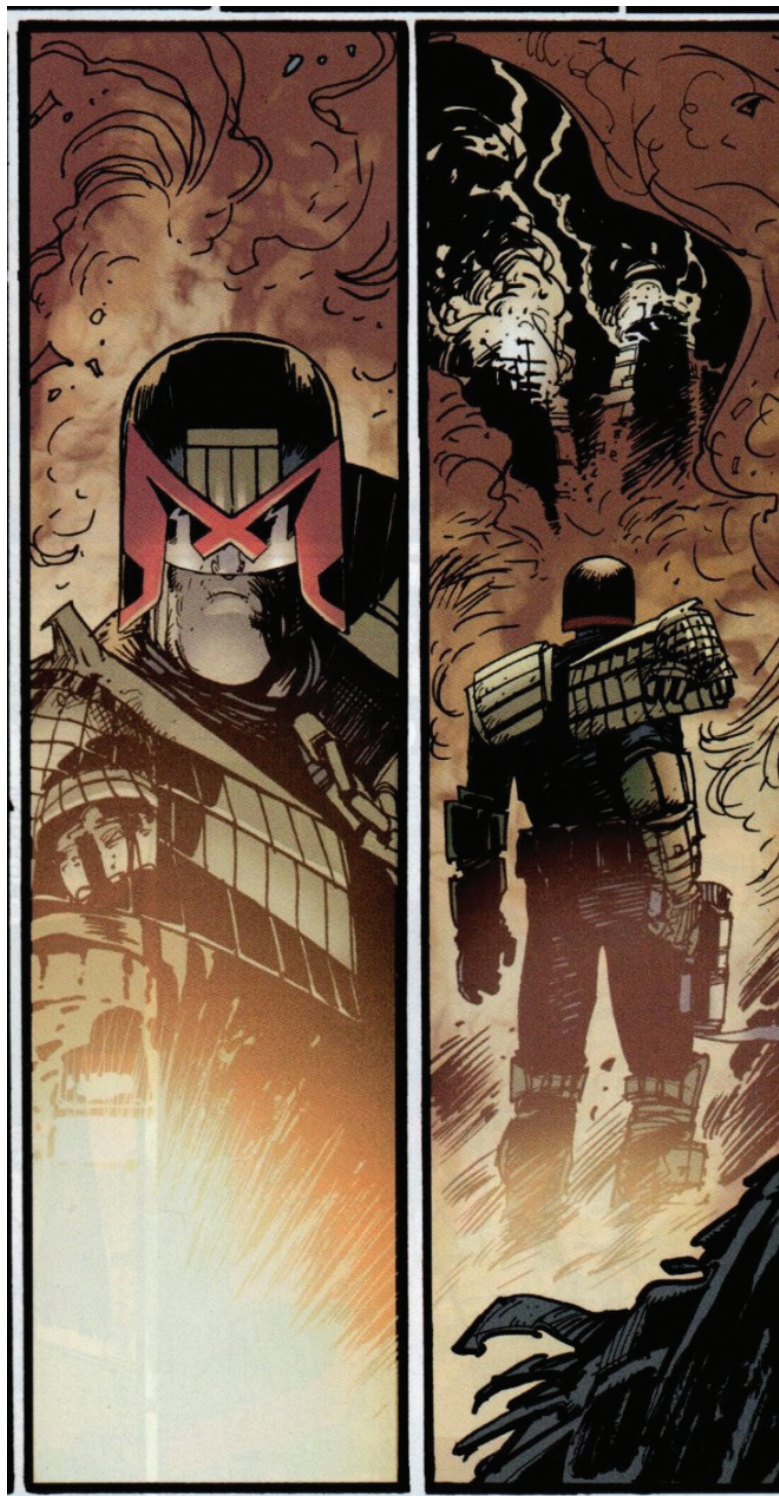

Fonte: WAGNER, John; FLINT, Henry, 2013

Uma marca que se mantém săo os olhos sempre escondidos pelo visor do capacete - sem o qual a personagem jamais é flagrada. É bastante significativo que uma personagem irrestritamente dedicada a manter a severa lei de seu mundo distópico tenha os olhos cobertos como a imagem da Justiça consagrada na cultura ocidental. Embora o visor náo o literalmente cegue como a faixa cega a Justiça, o efeito é análogo: os olhos de ambos sâo inacessíveis, cobertos por um véu que parece impedir a empatia para com o sujeito contemplado. Abaixo da superfície textual, Dredd nâo deixa de ser cego como a Justiça: nâo faz distinçăo entre aqueles que deve julgar - e executar.

Nunca retirado o capacete, nunca vistos seus olhos, Dredd é algo despersonalizado, conformado a uma uniformizaçăo total de suas açóes e pensamentos. Seu bordáo, repetido de forma exaustiva, é "Eu Sou a Lei", do qual se infere năo se tratar de um 
indivíduo personalizado, com anseios independentes do papel atribuído pelo Estado. Acentuando a despersonalizaçăo, todos os agentes da lei vestem-se como ele, e por vezes é dificultoso discernir qual dos personagens representados em determinado quadro é Dredd - recorrentemente, apenas o nome gravado no distintivo peitoral permite a identificaçăo.

A característica năo foi mantida na primeira adaptaçăo cinematográfica das histórias de Dredd, talvez para justificar o cachê do astro Sylvester Stallone. Na maior parte do longa-metragem, vemos a personagem sem o capacete, e o rosto do ator cujo nome encabeça o cartaz e as capas de home video fica à mostra. A opçáo pode também ter como impulso a tentativa de ampliar o leque dramático, já que um ator com os olhos escondidos tem limitados os recursos à disposiçăo. De qualquer forma, Dredd acaba por mostrar traços distintivos em meio aos que o cercam, e tanto a possível relaçăo com a figura da Justiça quanto a despersonalizaçáo da personagem se perdem. Constitui-se uma figura heróica afim aos parâmetros do cinema de açâo: além de singularizada, simultaneamente viril e simpática.

Figura 3: Still, do filme Judge Dredd

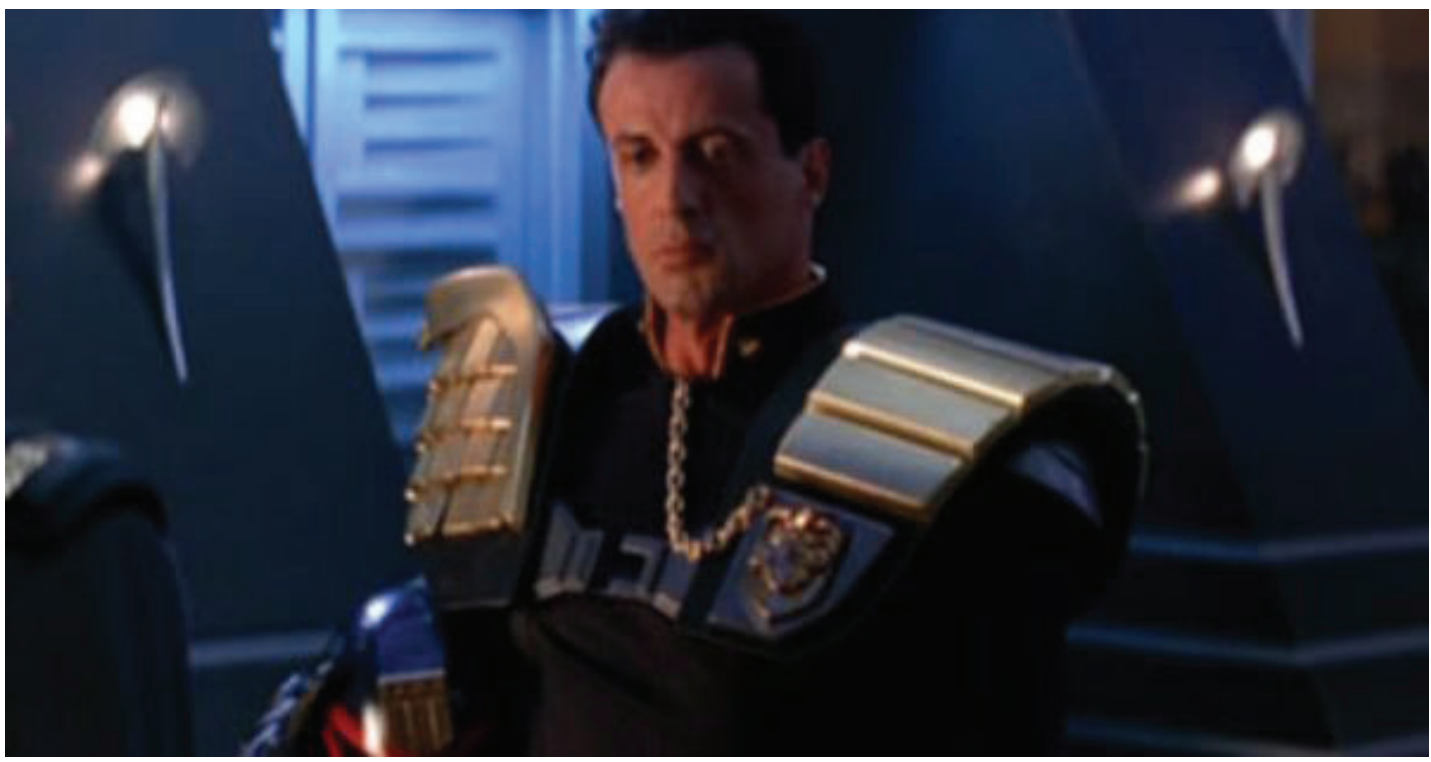

Fonte: CANNON, 1995

Caso distinto é o da segunda adaptaçâo cinematográfica, na qual o ator Karl Urban năo retira o capacete em nenhum momento. Como nos quadrinhos, há em cena também uma série de agentes da lei trajados como Dredd, sugerindo a uniformizaçăo e o consequente abandono de interesses particularizados. Curiosamente, um dos personagens principais é uma juíza5 em período probatório, que năo usa capacete para prevenir interferências em seus poderes telepáticos. Com o rosto à mostra, ela é particularizada em relaçăo aos demais agentes. Trata-se de uma opçăo produtiva, já que a personagem a carregar traços distintivos năo foi ainda uniformizada. Tem voz própria; năo é uma mera porta-voz da superior instância legal.

5 Os policiais são chamados de juízes, pois investigam e julgam os crimes. 
Figura 4: Still, do filme Dredd

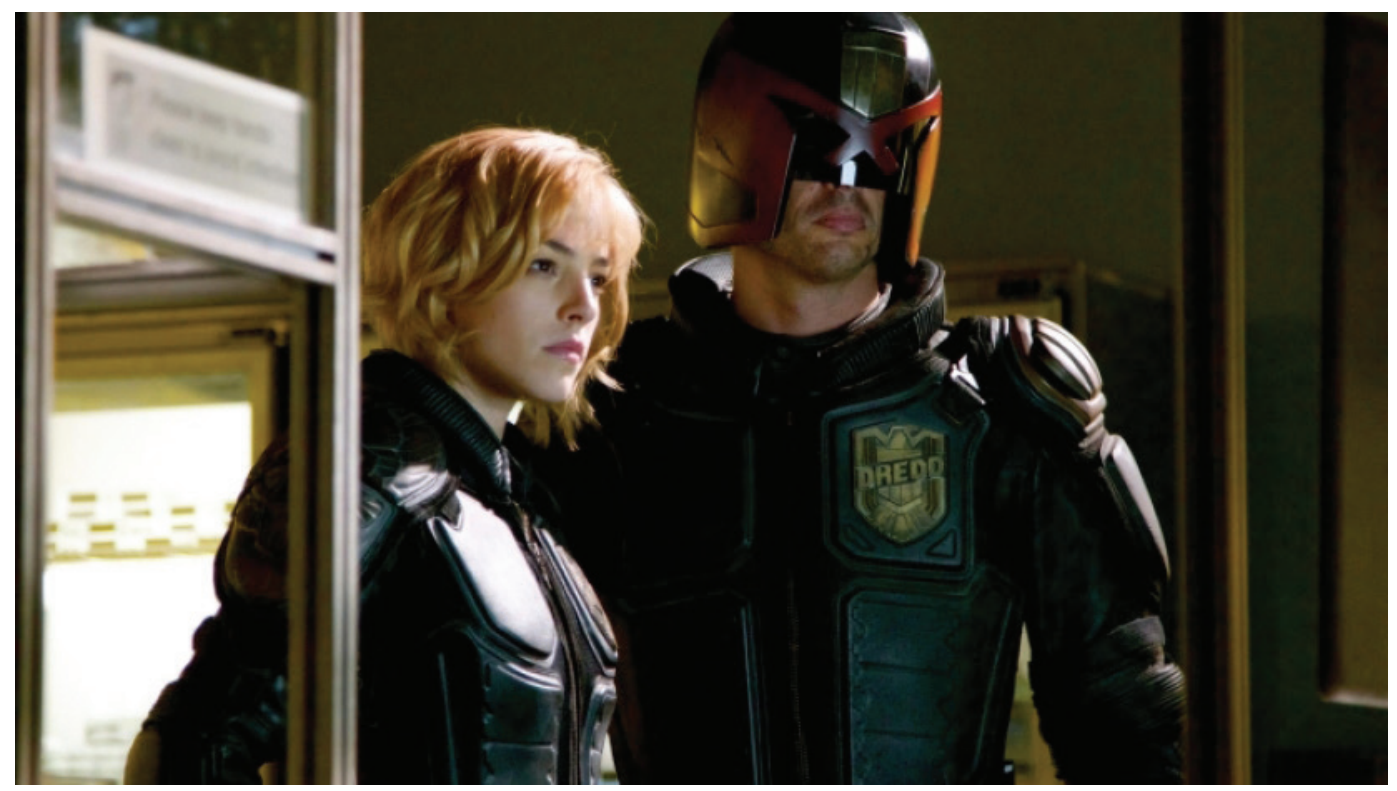

Fonte: TRAVIS, 2012

Cego a qualquer tipo de percepçăo crítica sobre os arredores, produto pleno de seu meio, Dredd náo pode ser pensado de maneira descolada da caótica cidade que patrulha, Mega-City Um. É uma metrópole absurdamente violenta e inchada, composta pela junçấo circunstancial, náo planejada, de diversos centros urbanos. Sua extensăo, embora nâo especificada nas histórias a compor nosso recorte, é gigantesca: na história em 12 partes intitulada "Guerra total", roteirizada por John Wagner, desenhada por Henry Flint, colorida por Chris Blythe e publicada nos números um a quatro da Juiz Dredd Megazine, bombas atômicas explodem em lugares específicos da cidade sem afetar diretamente os demais, um indicativo de que a metrópole é ampla o bastante para que explosóes dessa natureza fiquem contidas a bairros ou condomínios, eles próprios já tăo grandes como cidades.

Se Mega-City Um é um antro de inescapável violência, onde frutificam o comércio de drogas, o roubo, o assassinato, a exploraçăo de prostitutas, a corrupçăo e todos os tipos de crimes imagináveis, năo parece ser diferente além de seus limites: as referências esparsas a outras cidades sâo também marcadas pela negatividade. E, imediatamente atrás dos muros da supermetrópole, há um deserto radioativo habitado por gangues de mutantes que continuamente tentam invadir suas ruas para usufruir de um bastante precário ambiente urbano.

Simuladamente, extrapola-se para um futuro indeterminado a violência urbana contemporânea, bem como os malefícios que se estendem para além do asfalto e chegam a áreas nâo urbanizadas. A extrapolaçăo simulada é um procedimento caro a narrativas de ficçăo científica, e, em particular, às de cunho distópico: exagerando tendências em curso na contemporaneidade aos limites do insustentável, evidenciamse as deficiências dos nossos arredores imediatos. Realiza-se uma interaçâo entre o distanciamento e a cogniçâo, fomentando um olhar crítico acerca do real. Conforme a modelar formulaçăo de Darko Suvin: 
A ficçāo científica é um gênero literário cujas necessárias e suficientes condiçôes sāo a presença e a interaçáo do distanciamento e da cogniçâo, cujo principal dispositivo formal é um quadro imaginário alternativo ao do ambiente empírico do autor.6

Explicitemos o ponto, relacionando-o ao quadro imaginário configurado nas histórias de Dredd. Como veremos, as proposiçóes de Suvin podem servir para discutir objetos outros, e nâo apenas os literários. A projeçâo da violência urbana em um futuro indeterminado promove um novo olhar, crítico e cognitivo, acerca do ambiente empírico dos autores (e dos leitores). A lógica cognitivo-distanciada é operada pelos autores e concretizada no âmbito da recepçăo. Em outras palavras, a fim de que um novo olhar acerca do real seja promovido, a interaçâo referida por Suvin é operada pelos autores e fomentada nos leitores.

Como a violência de Mega-City Um é uma transfiguraçăo ficcional da observada nos centros urbanos de hoje, também Dredd o é das forças policiais que pretensamente tentam contê-la. Projetado na distopia futura, o policial tem seus traços extrapolados em exagero: truculento e completamente desinteressado dos interesses das minorias, age de maneira nada flexível e náo se adapta ao que cada nova circunstância exige.

Serve de exemplo a capa do Especial de Natal publicado no Brasil, que carrega um teor humorístico. Como um autômato incapaz de se adaptar a diferentes situaçóes porque possui uma programaçấo incompleta e sem nuances, Dredd nâo pode perceber o despropósito que é prender Papai Noel por invasăo a domicílio. Canhestro e desprovido do interesse de interpretar a lei, somente de aplicá-la, identifica a entrega anual de presentes com um crime a ser punido.

Figura 5: Capa da revista em quadrinhos Juiz Dredd Megazine Especial de Natal

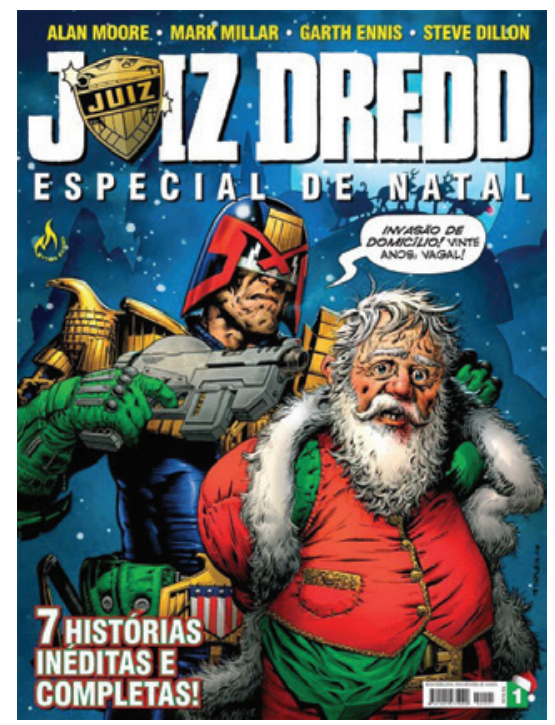

Fonte: EWING, Al; HIGGINS, John; HURST, Sally, 2013

Traduçâo livre de "SF is, then, a literary genre whose necessary and sufficient conditions are the presence and interaction of estrangement and cognition, and whose main formal device is na imaginative framework alternative to the author's empirical environment" (SUVIN, 2016, p. 20). 
Publicada na ediçăo, roteirizada por Al Ewing, desenhada por John Higgins e colorida por Sally Hurst, a história "Escolha o seu natal" ilustra a ausência de maleabilidade da personagem e o decorrente beco sem saída em que os cidadăos de Mega-City Um se veem encurralados. Formalmente ousada, a história tem cada um de seus quadros numerados e, como em um livro-jogo, cabe ao leitor escolher o destino da personagem principal, um cidadáo comum. Assim, ao final de alguns quadros específicos, há notaçôes como: "Deve ser a sua imaginaçăo. Se você quiser falar com o psiquiatra, ele está no quadro 9. Se ainda precisa comprar algo para a tia Flávia, pode ir para o quadro 36" (EWING, 2013, p. 36) ou "Na certa, é um terrível mal-entendido. Você vai fugir (vá para o 40)? Ou, e isso năo é recomendado, se entregar (vá para o 6)?" (EWING, op. cit.). Assim, a ordem de leitura náo é linear, mas determinada pela vontade do leitor - circunstância que, como veremos a seguir, é ela mesma colocada em xeque em determinado momento da história.

O protagonista da história, em um intertexto com O Processo, de Franz Kafka, vê-se acusado de um crime que desconhece. Articulando tema a forma, o labiríntico caminho que a personagem trilha em Mega-City Um é análogo às constantes idas e vindas operadas pelo leitor para construir a história. O problema é que todas as opçóes escolhidas pelo leitor levam a desfechos tragicômicos: ainda que aparentemente inocente, a personagem é sempre presa por Dredd ou morta tentando escapar da prisăo. Chega o momento, porém, em que se esgotam as opçōes e o leitor é forçado a concluir linearmente a leitura. Encurralado em um paradoxo espaço-temporal segundo o qual o criminoso seria uma versâo de si próprio oriunda de uma realidade alternativa, a personagem sofre dolorosos estertores a cada novo quadro lido de forma linear. Em suma, o próprio leitor se torna um agente de sua dor, ao lado do impassível e inexorável Dredd.

Figura 6: Página 40 da Juiz Dredd Megazine Especial de Natal

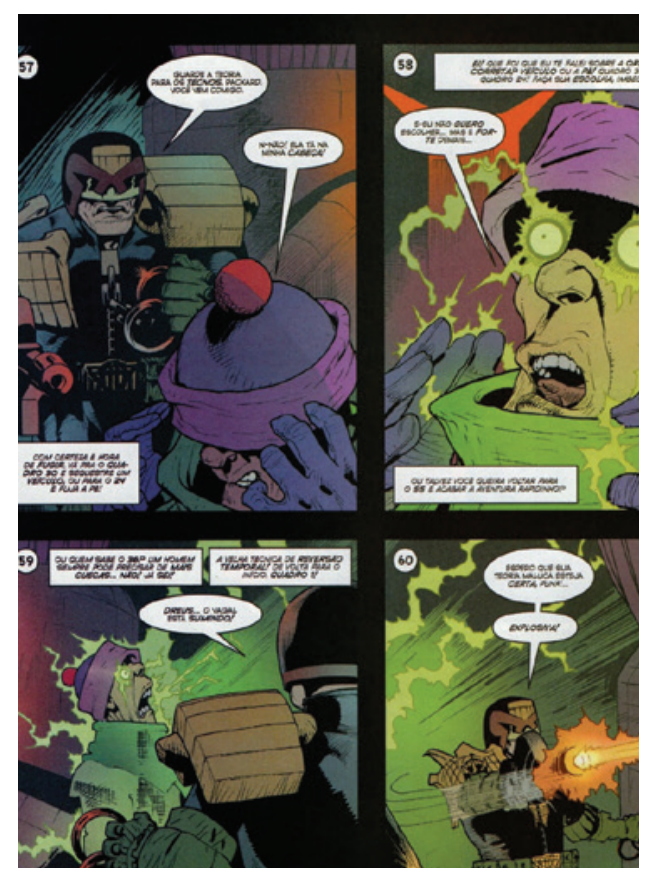

Fonte: EWING, Al; HIGGINS, John; HURST, Sally, 2013 
Outra história que leva ao extremo as açōes de Dredd é "Tempo esgotado", roteirizada por John Wagner, desenhada por Mike Collins, arte-finalizada por Cliff Robinson e publicada na Juiz Dredd Megazine, número 3. O protagonista foge freneticamente dos juízes, sem que ao leitor seja informado qual foi o crime cometido. Aparenta ser algo grave, dado o aparato policial movimentado para apanhá-lo e o desespero da fuga. Apenas no desfecho é revelada a natureza do crime: um livro emprestado da biblioteca doze anos antes e jamais devolvido. Significativamente, a obra em questăo é Guerra e Paz, de Leon Tolstói: a carência de sentido da guerra encontra sua análoga na açáo policial de Dredd.

Também cabe mencionar a história "Assassino geracional", roteirizada por John Wagner, desenhada por John Higgins e publicada na Juiz Dredd Megazine, número 10. Nela, um cidadăo de Mega-City Um, chamado Peart, se desespera ao saber que terá um filho. Segundo ele, todos os homens de sua família săo mortos no dia em que nascem seus primeiros rebentos. Surge entâo um viajante do tempo, o assassino geracional do título, e Dredd logo se prontifica a persegui-lo para impedir o assassinato. Năo consegue: o executor cumpre seu intento e desaparece no tempo, disposto a continuar sua jornada à procura dos homens da família que geram filhos. Resignado, Dredd conversa com a esposa de Peart, já com o recém-nascido no colo:

Figura 7: Detalhe da página 42 da Juiz Dredd Megazine, n. 10

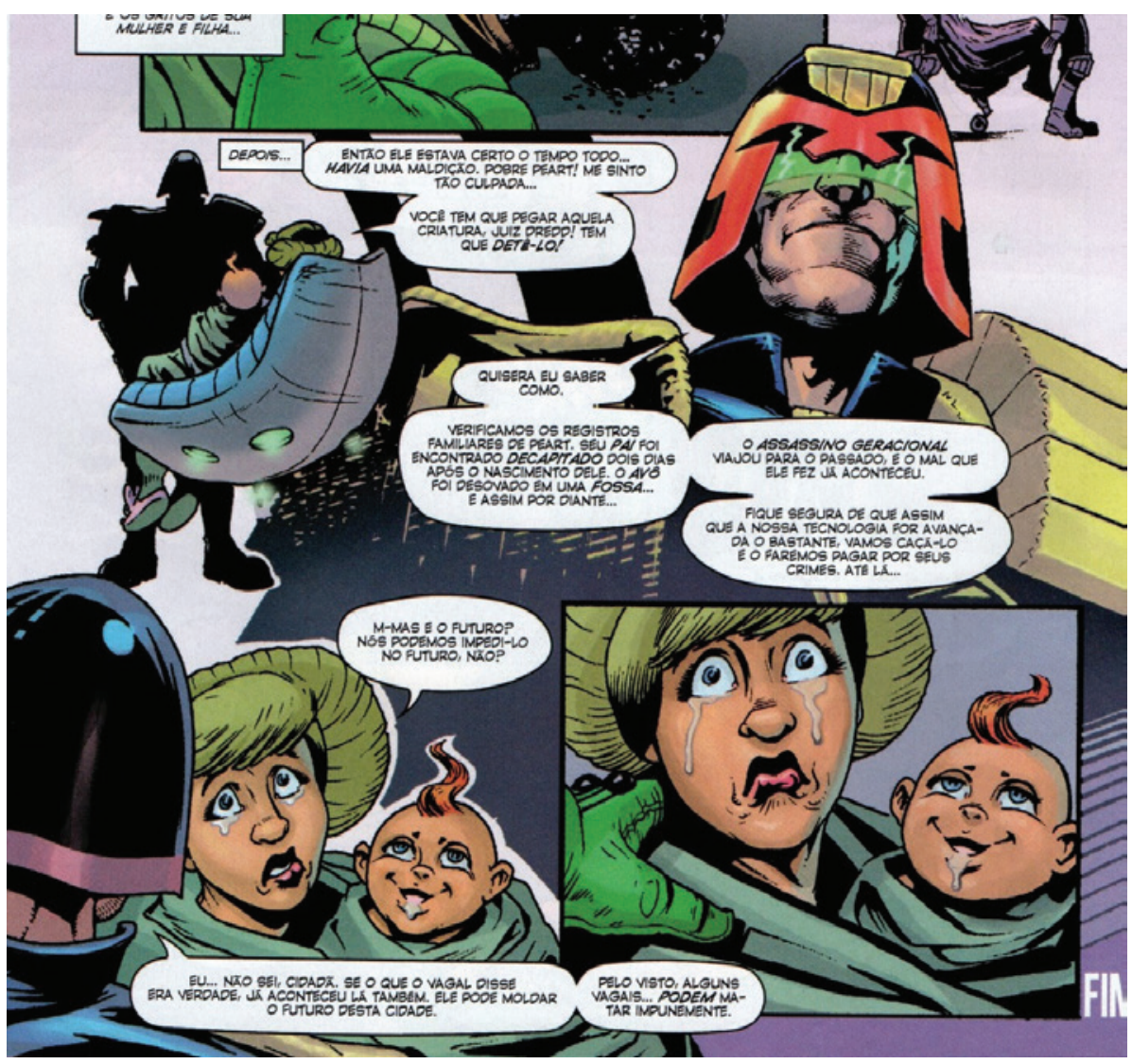

Fonte: WAGNER, John; HIGGINS, John, 2014 
Como é recorrente nas histórias de Dredd, no desfecho a justiça năo é feita, a despeito das convicçôes da personagem-título. A lógica determinista expressa em suas palavras tem a ver com o horror da vida na metrópole: o destino dos cidadáos é traçado desde o nascimento e eles podem apenas se conformar a uma nociva lógica imposta a priori. A prisâo ou a morte: estas sâo, comumente, as opçóes que restam aos personagens. Como o desavisado bebê de cuja boca escorre saliva, possuem limitada ou nenhuma capacidade de açăo, de escrever a própria história.

Salta aos olhos que Dredd nâo se apresenta como um herói modelar, do que é indício o tom cômico de algumas das histórias em que figura. Pelo contrário: apresenta-se como um retrato satírico de uma lei cuja aplicaçâo é indiferente às injustiças estruturais, podendo até mesmo reforçá-las. A possibilidade de comentário crítico acerca do real fomentada pela ficçáo científica se verifica de maneira plena e Dredd acrescenta novos nuances à personagem distópica tradicional. Sua própria impossibilidade de mudar o particulariza. Ao contrário do típico protagonista da distopia, Dredd năo pode questionar as estruturas de seu mundo, uma imobilidade que satiricamente denuncia como nocivo o "excesso de ordem".

Caso contrário é o de ambas as adaptaçôes cinematográficas: nelas, a personagem é um herói indefectível, e as contradiçôes inerentes ao sistema que o conforma nâo săo representadas. Ambas as narrativas, a despeito de suas singularidades, apontam a açáo de Dredd como passível de resolver os problemas confrontados e fazer a justiça prevalecer por meio da aplicaçăo estrita da lei. A segunda adaptaçăo, aparentemente mais apegada às histórias originais, acaba por ser ainda mais radical na diferença: se o mantenedor da justiça é desprovido de individualidade, acaba sendo promovido um elogio do apagamento das diferenças e da violência como melhor resposta à criminalidade. Um sentido simetricamente antagônico ao veiculado pela personagem em sua mídia de origem, as histórias em quadrinhos.

Observemos que a narrativa matriz foi modificada sem o acréscimo de um novo nuance, antes com o apagamento dos índices que possibilitariam um retorno ao real capaz de colocar em suspenso as estruturas vigentes no empírico. Para Theodor W. Adorno e Max Horkheimer em Dialética do Esclarecimento, a indústria cultura opera por meio de uma homogeneizaçâo:

As vantagens e desvantagens que os conhecedores discutem servem apenas para perpetuar a ilusăo da concorrência e da possibilidade de escolha. [...] Os valores orçamentários da indústria cultural nada têm a ver com os valores objetivos, com o sentido dos produtos. Os próprios meios técnicos tendem cada vez mais a se uniformizar (ADORNO; HORKHEIMER, 1985, p. 102).

A uniformizaçăo, no caso em pauta, é a conformaçăo da personagem a um modelo pré-estabelecido de herói cinematográfico: correto, moralmente bem resolvido e sempre disposto a, com a ira dos justos, fazer uso da força física. É esclarecedora a proposiçăo de Adorno e Horkheimer segundo a qual a indústria cultural toma para si as perspectivas críticas surgidas em seu seio, cuidando de deixá-las estéreis.

Nos quadrinhos, a personagem ainda se mantém capaz de promover um olhar outro acerca da polícia empírica, mesmo nas máos de diversos roteiristas. É uma circunstância 
que merece investigaçăo, posto que as proposiçōes de Adorno e Horkheimer acerca da indústria cultural indicam que a mera produçăo em série provocaria um esvaziamento do sentido - lembremos que Dredd é publicado no decorrer de várias décadas, o que caracteriza uma produçâo seriada.

Estamos diante de um indício que permite o estabelecimento da seguinte hipótese: a indústria cultural, representada por executivos interessados em propriedades que rendam dividendos, mantém um controle menor em instâncias de menor alcance no mercado consumidor e, consequentemente, capazes de gerar menor lucro. É o caso dos quadrinhos de Dredd, comparativamente a um longa-metragem encabeçado por Stallone e obrigado a recuperar os milhōes de dólares nele investidos. Mesmo a segunda adaptaçâo cinematográfica, de orçamento enxuto, parece opulenta diante do custo necessário para produzir uma história em quadrinhos destinada a mercados menores, como é o caso da 2000 a. D. Desprovida da obrigaçăo de fornecer dividendos realmente volumosos, a distopia de Dredd preserva seu potencial acidamente subversivo nos quadrinhos. 


\section{Referências Bibliográficas}

ADORNO, Theodor W.; HORKHEIMER, Max. Dialética do esclarecimento. Rio de Janeiro: Zahar, 1985.

BRADBURY, Ray. Fahrenheit 451. Traduçăo: Donaldson M. Garschagen. Săo Paulo: Círculo do Livro, [s.d.].

BRANDÂO, Ignácio de Loyola. Năo Verás País Nenhum. Sâo Paulo: Global, 1985.

DREDD: Reliance Entertainment. Direçâo: Pete Travis. 2012. 95 min.

ECO, Umberto. A literatura contra o efêmero. Folha de Săo Paulo, Sáo Paulo, 18 fev. 2001.

Seis passeios pelos bosques da ficçăo. Traduçâo: Hildegard Feist. Sâo Paulo: Companhia das Letras, 1994.

EWING, Al; HIGGINS, John; HURST, Sally. Escolha o seu natal. Juiz Dredd Megazine. Săo Paulo, 2013. Ediçăo especial de Natal.

HUXLEY, Aldous. Brave new world. New York: Harper Collins, 1998.

Brave new world revisited. 2000.

JUDGE DREDD. Direçăo: Danny Cannon. Hollywood Pictures, 1995. 96 min.

MILLS, Pat; MCMAHON, Mike. O retorno de Rico. Juiz Dredd Megazine, Săo Paulo, n. 2, 2013.

ORWELL, George. 1984. New York: New American Library, [s.d.].

SUVIN, Darko. Metamorphoses of science fiction. Bern: Peter Lang, 2016.

WAGNER, John; COLLINS, Mike; ROBINSON, Cliff. Tempo Esgotado. Juiz Dredd Megazine, Săo Paulo, n. 3, 2013.

; FLINT, Henry. Guerra total, parte 12. , n. 4, 2013.

.HIGGINS, John. Assassino geracional. n. 10, 2014. 